\title{
KONFLIK TANAH HIBAH MASYARAKAT NELAYAN DENGAN PEMERINTAH KABUPATEN ACEH BARAT
}

\author{
Nurlian \\ Prodi Sosiologi FISIP Universitas Teuku Umar \\ siti.lian82@yahoo.com
}

\begin{abstract}
These conflicts arise because people demanded compensation for land area of 16.1 hectares that has been occupied for six months as a substitute homeland of the fishing community in the village of Padang Seurahet due West Aceh District Government states that the land area of 16.1 hectares located in the village of Pasie Pinang is Government land. Buildings constructed on this land if the Sports and Arts (GORS). The purpose of this study to determine the root causes of conflict and ways of conflict resolution sociology, namely Negotiation, Mediation and Conciliation. The theory used is George Simmel conflict theory and Lewis Coser.untuk REMEDY conflict analysis used the concept of conflict resolution negotiation, mediation and conciliation in the paradigm of sociology. Qualitative research methods were used to obtain research data. The research found that, the Government of West Aceh found, can not be compensated on the ground because it does not do grant legally to the public and the public has been getting its due in the relocation of another tsunami, a native lands in the village of Padang Seurahet been replaced by land and houses in the permanent housing aid donors. Conflict settlement initially reached by way of negotiation and conciliation by the Government of West Aceh District, but did not find the solution, so that the final resolution adopted by law (litigation).
\end{abstract}

Keywords: Land Conflict, Government, Fishermen Society and Conflict Resolution

\begin{abstract}
Abstrak
Konflik ini muncul dikarenakan masyarakat menuntut ganti rugi atas tanah yang seluas 16,1 Hektar yang telah ditempati selama 6 bulan sebagai pengganti tanah asal masyarakat nelayan di Desa Padang Seurahet dikarenakan Pemerintah Kabupaten Aceh Barat menyatakan bahwa tanah seluas 16,1 hektar yang terletak di Desa Pasie Pinang adalah tanah Pemerintah. Diatas tanah ini dibangun Gedung olah Raga dan Seni (GORS). Tujuan penelitian ini untuk mengetahui akar permasalahan konflik dan cara penyelesaian konflik secara sosiologi, yaitu Negoisasi, Mediasi dan Konsiliasi. Teori yang digunakan adalah teori konflik George Simmel dan Lewis Coser.untuk analisis penyelesian konflik digunakan konsep penyelesaian konflik negoisasi,mediasi dan konsiliasi dalam paradigma sosiologi. Metode penelitian kualitatif yang digunakan untuk mendapatkan data-data penelitian.Hasil penelitian menemukan bahwa, Pemerintah Kabupaten Aceh Barat berpendapat bahwa, tidak bisa diganti rugi atas tanah tersebut dikarenakan belum dilakukan penghibahan secara hukum kepada masyarakat
\end{abstract}


dan masyarakat tersebut telah mendapatkan haknya di relokasi lain pasca bencana tsunami, tanah asal di Desa Padang Seurahet sudah tergantikan oleh tanah dan rumah di perumahan permanen bantuan lembaga donor. Penyelesaian konflik awalnya ditempuh dengan cara negoisasi dan konsiliasi oleh Pemerintah Kabupaten Aceh Barat, akan tetapi tidak menemukan penyelesaiannya, sehingga penyelesaian akhir ditempuh secara hukum (litigasi).

\section{KATA KUNCI: Konflik Tanah, Pemerintah, Masyarakat Nelayan dan Penyelesaian Konflik}

\section{PENDAHULUAN}

Tanah hibah yang berada di Gampong Pasie Pinang Kecamatan Meureubo adalah tanah yang dibeli oleh Pemerintah Kabupaten Aceh Barat sebesar Rp.638.435.000 (enam ratus tiga puluh delapan juta empat ratus tiga puluh ribu) yang tertulis dalam Berita Acara Pembelian nomor :03/PPT/AB/2004. Pengadaan tanah ini diperuntukkan untuk masyarakat nelayan dari Gampong Padang Seurahet untuk menempatinya. Masyarakat Padang Seirahet di pindahkan kelokasi ini sebelum tsunami 2004 melanda wilayah Aceh dikarenakan faktor abrasi parah disepanjang pesisir wilayah Kabupaten Aceh Barat. Jumlah keluarga pengungsi yang menempati lahan 16 Ha tersebut sejumlah 112 KK dari Gampong Padang Seurahet dan masyarakat nelayan dari Gampong Suak Indrapuri sebanyak $21 \mathrm{KK}$.

Pada tanggal 15 November 2013 Pemerintah Kabupaten Aceh Barat (periode 2012-sekarang) menyatakankan kembali bahwa, tanah hibah tersebut adalah milik

Pemerintah Kabupaten Aceh Barat dan masyarakat nelayan melakukan aksi demontrasi besar-besaran sebagai bentuk perlawanan atas pernyataan Pemerintah. Aksi pertama yang dilakukan adalah dengan memasang spanduk di lahan yang disengketakan dengan menulis "Mohon Pemkab Jangan Rampas Hak Masyarakat", kemudian melanjutkan aksi demo ke Kantor DPRK Kabupaten Aceh Barat, Kantor Bupati Aceh Barat dan ke Polres Aceh Barat untuk meminta dukungan penyelesaian konflik tanah masyarakat nelayan dengan Pemerintah Kabupaten Aceh Barat.

\section{TINJAUAN PUSTAKA}

\section{Teori Konflik Kontemporer}

Teori konflik kontemporer lahir oleh adanya kritikan terhadap teori konflik Karl Marx yang hanya terfokus pada konflik perjuangan kelas antara kelas pemodal (borjuis) dengan kelas buruh (proletar) dalam masyarakat industri di abad ke 19. Kritikan ini disampaikan juga oleh Lewis Coser dalam Poloma (2010: 129) mengatakan bahwa, teori konflik Karl Marx adalah teori konflik fungsional sruktural tradisional sebagai benih lahirnya pembentukan teori sosiologi konflik komtemporer, kemudian oleh Ralh 
Dahrendorf dalam Poloma (2010:130-131) melihat bahwa, konflik sosial di abad 20 telah berubah posisinya yaitu, konflik sosial tidak lagi terjadi pada kelas atas dan kelas bawah, akan tetapi dalam konflik masyarakat modern, konflik terjadi pada ketiga kelas sosial tersebut. Konflik sosial dalam pandangan teori konflik komtemporer melihat bahwa, dalam konflik sosial yang terjadi sekarang telah terjadi dekomposisi modal pada sistem kapitalisme, dekomposisi tenaga kerja (profesionalisme perkerjaan) dan munculnya kelas menengah baru yang menyebabkan terjadinya konflik sosial. Teori konflik komtemporer ini melihat bahwa, konflik sosial tidak hanya terjadi dalam lingkup sistem kapitalisme saja, akan tetapi diluar sistem tersebut tetap terjadi konflik sosial dengan motif dan keperntingan konflik yang berbeda.

Selanjutnya Coser dalam Wirawan (2012:82) mengatakan bahwa, konflik sosial yang terjadi pada interkasi sosial yang terjalin memberikan konsekuensi-konsekuensi untuk sistem yang lebih besar, dari pada konflik yang terjadi interaksi secara individu yang di jelaskan oleh Simmel. Coser dalam Wirawan (2012:83) mengatakan bahwa, konflik sebagai perselisihan mengenai nilai-nilai atau tuntutan-tuntutan berkenaan dengan status, kekuasaan dan sumber-sumber kekayaan yang persediaannya tidak tercukupi yang terjadi antara individu, kumpulan atau antara individu dengan kelompok. Lewis Coser (1959:49) berpandangan bahwa, konflik realistis memiliki sumber konkret atau bersifat material, seperti perebutan sumber ekonomi atau wilayah. Jika pelaku konflik telah memperoleh sumber konflik tersebut tanpa perkelahian, maka konflik akan teratasi dengan baik. Sedangkan konflik non-realistis adalah konflik yang didorong oleh faktor yang tidak rasional dan cenderung bersifat ideologis, seperti konflik antar agama,antar etnis dan antar kepercayaan.

\section{Penyelesaian Konflik Dalam Paradigma Sosiologi}

Basis sosiologis penyelesaian konflik disebut resolusi konflik non-litigasi. Penyelesaian konflik secara non-litigasi dikenal dengan konsep negoisasi, mediasi dan konsiliasi. Menurut Leo Kanowitz dalam Abu Rohmad (2002:142-146) yaitu penyelesaian sengketa non-ligitasi memiliki karakteristik yang unik, yaitu, pelaksanaan perundingan bersifat pribadi atau rahasia, forum dikontrol oleh para pihak, mempunyai tujuan untuk merefleksikan kepentingan dan prioritas para pihak, mempertahankan keberlanjutan hubungan para pihak, pelakasanaannya fleksibel dan putusannya cenderung dijalankan oleh para pihak yang bertikai.

Berkaitan dengan pernyataan diatas, maka penyelesaian konflik non-ligitasi belum tentu dapat menyelesaikan semua masalah yang terjadi, akan tetapi membawa beberapa keuntungan dalam proses penyelesaian konflik yaitu, (1) penyelesaian konflik non-ligitasi dapat mengurangi kemacetan dan penumpukan perkara (court congestion) di lembaga pengadilan, (2) Untuk dapat meningkatkan keterlibatan masyarakat (desentralisasi hukum) atau memberdayakan pihak-pihak yang bersengketa dalam menyelesaikan masalahnya (3), Untuk memperlancar akses masyarakat memperoleh 
keadilan (acces to justice) (4), Untuk memberikan kesempatan bagi tercapainya penyelesaian yang menghasilkan keputusan saling menguntungkan (win-win solution) (5), Untuk memudahkan perkara lebih cepat dan biayanya lebih murah, (6) Bersifat tertutup atau rahasia (confidential) dalam proses penyelesaian konflik non-litigasi, (7) Lebih tinggi kemungkinan dilaksanakan kesepakatan bersama sehingga hubungan pihak-pihak yang bersengketa selanjutnya masih terjalin dengan baik, (8) Mengurangi merebaknya "permainan kotor" dalam lembaga peradilan dan (9) Mampu memenuhi segitiga kepuasan (triangle satisfaction) dalam mendapatkan kesepakatan damai yang disepakati bersama.

Menurut Abu Rohmah (2002:132-133) mengatakan bahwa, negosiasi adalah penyelesaian sengketa yang dilaksanakan sendiri oleh pihak yang bersengketa tanpa melibatkan pihak ketiga. Dalam UU No.30 Tahun 1999 Pasal 6 ayat (2) dijelaskan bahwa, dimana hasil kesepakatan tersebut harus dituangkan dalam bentuk tertulis yang ditandatangani oleh kedua belah pihak yang bertikai. Kemudian Mark E. Roszkowski dalam Abu Rohmah (2002:133) menyatakan bahwa, negosiasi adalah suatu proses penyelesaian sengketa dimana kedua belah pihak yang memiliki tuntutan berbeda membuat sautu kesepakatan melalui kompromi dan konsesi (kelonggaran).

Menurut Adi Sulistoyo dalam Abu Rohmah (2002:137) mengatakan bahwa, konsiliasi adalah merupakan upaya penyelesaian sengketa melalui perundingan dengan melibatkan pihak ke tiga yang netral untuk membantu para pihak yang bertikai menemukan bentuk-bentuk penyelesaian konflik yang dapat disepakati bersama dalam perundingan secara formal dimana peranannya lebih banyak diperankan oleh konsiliator dalam berupaya menemukan penyelesaian konflik (sengketa). Selanjuntnya Black dalam Wijoyo (1998:104) mengatakan bahwa konsiliasi seringkali lebih formal dari mediasi, dan Oppenheim dalam Emirzon (2001:91) menjelaskan konsiliasi adalah proses penyelesaian sengketa dengan menyerahkan kepada suatu komisi yang bertugas untuk menguraikan atau menjelaskan fakta dan biasanya setelah mendengar para pihak dengan mengupayakan pihak yang berkonflik mencapai suatu kesepakatan dan membuat usulan-usulan untuk penyelesaian konflik.

\section{METODE PENELITIAN}

Penelitian ini menggunakan metode penelitian kualitatif dengan penyajian secara deskriptif. Penelitian kualitatif menurut Yin Robert (1994: 13) adalah penelitian yang merupakan salah satu bentuk penelitian empiris yang melakukan investigasi terhadap fenomena kontemporer dalam konteks kehidupan yang nyata khususnya ketika batasan antara fenomena dan konteks tidak mempunyai pembuktian yang jelas. Penyajian data penelitian disajikan dalam bentuk deskriptif, tujuannya untuk menggambarkan dan memahami kehidupan masyarakat dalam konstek keutuhan sebagai suatu kesatuan. Pendeskripsian dilakukan dengan secara analitis tentang apa penyebab pengambilalihan tanah hibah. Pengumpulan data dikumpulkan dengan observasi, wawancara dan 
pendokumentasian (catatan tertulis dan foto yang ditemukan dilapangan) yang itu dari data primer dan data sekunder. Data-data tersebut di analisis teknik pengumpulan datadimulai dengan mengumpulkan semua informasi,selanjutnya dilakukan pengakatogarian data.

\section{HASIL DAN PEMBAHASAN}

Persepsi masyarakat nelayan dan Pemerintah Kabupaten Aceh Barat terhadap munculnya konflik adalah di saat masyarakat nelayan yang menempati lokasi tanah seluas 16,1 Ha tersebut dipindahkan kembali kerelokasi baru pasca bencana tsunami, yaitu ke Perumahan bantuan Desa Blang Beurandang dan Desa Pasie Mesjid dengan diatas sertifikasi atas nama masyarakat nelayan tersebut. Pendapat Pemerintah Kabupaten Aceh Barat mempersepsikan bahwa tanah dan rumah bantuan yang telah diterima oleh masyarakat nelayan adalah sebagai cara yang adil untuk menggantikan tanah asal masyarakat nelayan yang berada di Desa Padang Seurahet, tetapi persepsi ini berbeda dengan masyarakat nelayan Desa Padang Seurahet bahwa tanah dan rumah yang diterima tersebut adalah sudah selayaknya diterima dikarenakan korban tsunami, tidak sebagai tanah pengganti tanah asal masyarakat nelayan di Desa Padang Seuarahet.

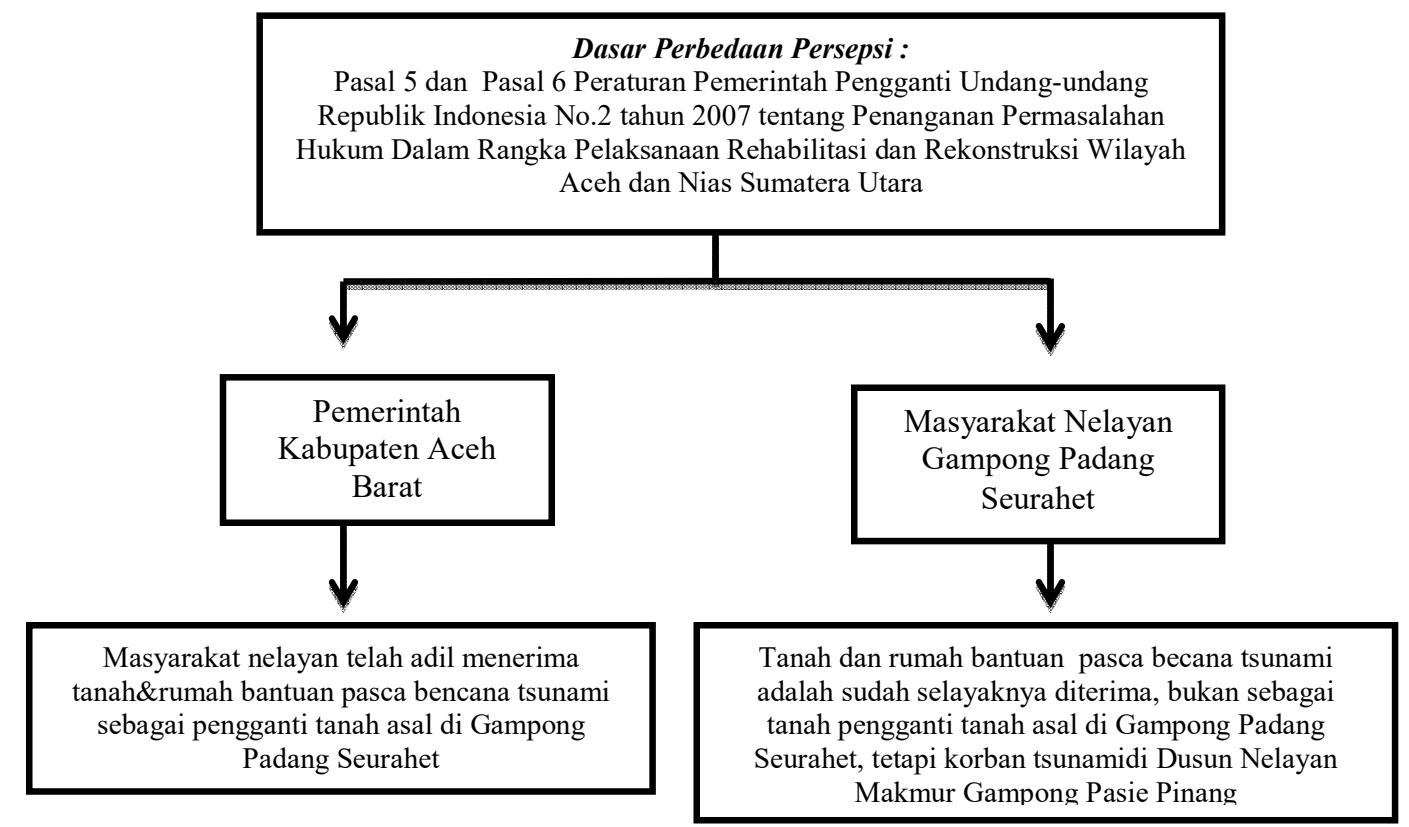

Sumber: Analisis Data Penelitian, September 2016

Gb. 1 Skema Perbedaan Persepsi terhadap relokasi pasca bencana tsunami oleh Pemerintah Kabupaten Aceh Barat dan Masyarakat Nelayan Gampong Padang Seurahet 
Konflik yang terjadi antara masyarakat nelayan dengan Pemerintah Kabupaten Aceh Barat adalah bentuk konflik realistis. Konflik realistis seperti penjelasan diatas, bahwa wujud konflik tersebut adalah perebutan tanah sebagai sumber ekonomi masyarakat. Dimana masyarakat nelayan menjadikan tanah tersebut sebagai modal untuk mencari penghidupan dan tempat tinggal. Konflik ini terjadi dikarenakan oleh adanya tuntutan kepada Pemerintah Kabupaten Aceh Barat yang tidak di wujudkan, yaitu ganti rugi tanah seluas 16,1 Ha dikarenakan tanah tersebut digunakan oleh Pemerintah Kabupaten Aceh Barat untuk membangun Gedung Olah Raga dan Seni (GORS), sehingga masyarakat nelayan merasa dirugikan dan melakukan aksi demontrasi sebagai bentuk perlawanan kepada Pemerintah Kabupaten Aceh Barat. Aksi demontrasi yang dilakukan juga sebgaai bentuk kekecewaan terhadap Pemerintah Kabupaten Aceh Barat yang terakumulasi secara massal. Penjelasan selanjutnya adalah, masyarakat nelayan melahirkan energi-energi agresif atau melakukan aksi demontrasi secara berani dan massal, juga melakukan proses interaksi (membuka hubungan) dengan pihak-pihak lain yang bisa berperan untuk membantu mewujudkan keinginan masyarakat nelayan ini. Wujud hubungan interaksi yang dilakukan dengan pihak lain adalah masyarakat nelayan (Perwakilan Kelompok Aksi) melakukan negoisasi pada Lembaga Bantuan Hukum Pos Meulaboh untuk meminta dukungan dan dampingan secara hukum. Hubungan interaksi yang dilakukan oleh masyarakat nelayan atau perwakilan kelompok aksi dengan pihak Lembaga Bantuan Hukum dimana ketengangan konflik tersebut belum mereda/belum selesai. Untuk analisis teoritis pada konflik tanah hibah masyarakat nelayan dengan Pemerintah Kabupaten Aceh Barat, maka teori konflik ini sangat sesuai dengan yang terjadi dilokasi penelitian.

Sesuai fakta yang ditemukan, konflik yang terjadi dilapangan adalah konflik Vertikal. Menurut Suadi,dkk (2003:41-42) konflik terjadi dalam setiap masyarakat harus dilihat sebagai jenis dan tipe konflik seperti apa, sebelum memberikan penyelesaiannya. Konflik vertikal adalah konflik kelas atas atau konflik yang memperlihatkan perseteruan antara elite dengan massa (rakyat). Elite disini dikatakan sebagai pengambil kebijakan di tingkat pusat, kelompok bisnis atau militer. Konflik vertikal ditonjolkan oleh adanya instrumen kekerasan negara sehingga menimbulkan korban dikalangan massa. Dalam hal ini, sesuai penemuan data dilapangan bahwa, ditemukan konflik perebutan tanah tidak mengandung unsur kekerasan fisik, akan tetapi masyarakat nelayan mendapatkan tekanan-tekanan melalui kekuatan hukum. Kekuatan hukum yang dimaksudkan disini adalah, proses hukum dan hasil yang didapatkan cenderung berpihak kepada Pemerintah. Hasil proses hukum tersebut terdapat dalam bukti kepemilikan status tanah yaitu, Pemerintah Kabupaten Aceh Barat berdasarkan Temuan Tim Pencari Fakta, Temuan Tim Pansus DPRK, Pendapat Hukum Nomor: B1042/N.1.16/Gs.1/06/2015 dari Kantor Kejaksaan Negeri Meulaboh dan Hasil Keputusan Komisi Informasi Aceh dan masyarakat nelayan tidak mempunyai bukti yang kuat atas masalah ini. 
Bentuk tekanan selanjutnya dalam bentuk penyembunyian informasi publik tentang Berita Acara Relokasi Masyarakat Nelayan dari Gampong Padang Seurahet Kecamatan Johan Pahlawan ke Gampong Pasie Pinang Kecamatan Meureubo pada tahun 2004, Data dan penjelasan bukti yang menyatakan tanah tersebut adalah tanah Pemda Aceh Barat, Data dan Penjalasan terkait Keputusan Presiden Pencabutan hak masyarakat di Gampong Padang Seurahet Kecamatan Johan Pahlawan Kabupaten Aceh Barat. Ketiga bukti ini tidak dipunyai oleh masyarakat nelayan dari Gampong Padang Seurahet, sehingga masyarakat tersebut tidak melanjutkan lagi penyelesaian konflik ini ke jalur hukum.

Dalam hal ini, kontribusi positif konflik yang terjadi antara masyarakat nelayan dengan Pemerintah Kabupaten Aceh Barat adalah kelompok masyarakat nelayan semakin kuat dan solid dalam proses perlawanan untuk mendapatkan tanah atau ganti rugi tanah yang disengketakan. Kekuatan solidaritas kelompok dalam pengumpulan dana demonstrasi dimana dana/biaya tersebut di berikan sukarela oleh masyarakat nelayan. Selain itu, sumbangan dana untuk kelompok masyarakat nelayan yang berjuang tersebut didapatkan dari Kelompok Gabungan Tukang Becak Kabupaten Aceh Barat (GAPENCAK). Bentuk solidaritas kelompok ini terwujud akibat dari konflik vertikal yang terjadi antara masyarakat nelayan dengan Pemerintah Kabupaten Aceh Barat. Kekuatan solidaritas ini telah mempersatukan persepsi masyarakat nelayan akan kepentingan yang diinginkan yaitu menuntut ganti rugi tanah kepada Pemerintah Kabupaten Aceh Barat.

Penemuan data wawancara dan data tertulis yang didapatkan dilapangan bahwa, pihak Pemerintah Kabupaten Aceh Barat telah mengupayakan proses penyelesaian konflik secara non-litigasi (diluar pengadilan) dengan masyarakat nelayan. Peran Pemerintah Kabupaten Aceh Barat telah melakukan koordinasi dan rapat-rapat dengan instansi yang terkait secara formal. Analisis Sosiologi Pemerintahan oleh Simon dalam Geert P.A. Bram (2008:254) mengatakan bahwa" Pemerintah memainkan peranan untuk pengumpulan informasi tentang jenis masalah, mengeluarkan ketrampilan-ketrampilan dari angggota kelompok dan kemungkinan-kemungkinan kombinasinya dan komunikasi dengan mendayagunakan elemen-elemen dengan tepat, sehingga diperlukan gambaran dari proses pembentukan keputusan itu" sehingga upaya Pemerintah Kabupaten Aceh Barat melakukan koordinasi dari suatu proses pembentukan keputusan yang komplek untuk menganalisis permasalahan yang dalam hal ini adalah masalah tanah antara masyarakat nelayan dengan Pemerintah Kabupaten Aceh Barat.

Upaya penyelesaian konflik tahap negoisasi ini tidak mendapatkan suatu perjanjian untuk mengakhiri konflik dengan masyarakat nelayan dikarenakan, masyarakat nelayan tetap menuntut ganti rugi tanah tersebut, karena tanah tersebut dianggap adalah tanah sah milik masyarakat nelayan berdasarkan Pasal 5 dan Pasal 6 Peraturan Pemerintah Pengganti Undang-Undang Tentang Penaganan Permasalahan 
Hukum Dalam Rangka Pelaksanaan Rehabilitasi dan Rekonstruksi Wilayah dan Kehidupan Masyarakat Di Provinsi Nanggroe Aceh Darussalam dan Kepulauan Nias Sumatera Utara.

Sehubungan dengan uraian diatas, maka penyelesaian konflik secara non-litigasi antara masyarakat nelayan dengan Pemerintah Kabupaten Aceh Barat tidak menghasilkan suatu perjanjian untuk menggakhiri konflik, akan tetapi masyarakat tetap dengan pendiriannya untuk mendapatkan ganti rugi tanah tersebut yang telah digunakan oleh Pemerintah Kabupaten Aceh Barat untuk membangun Gedung Olah Raga dan Seni. Perseteruan ini pada akhirnya Pemerintah Kabupaten Aceh mengambil kebijakan upaya penyelesaian konflik ke jalur hukum kepada masyarakat nelayan untuk menaikkan tuntutannya ke pengadilan, akan tetapi masyarakat nelayan tidak melanjutkan penyelesaian konflik ini kepengadilan, dikarenakan tidak kuatnya bukti yang dimiliki.

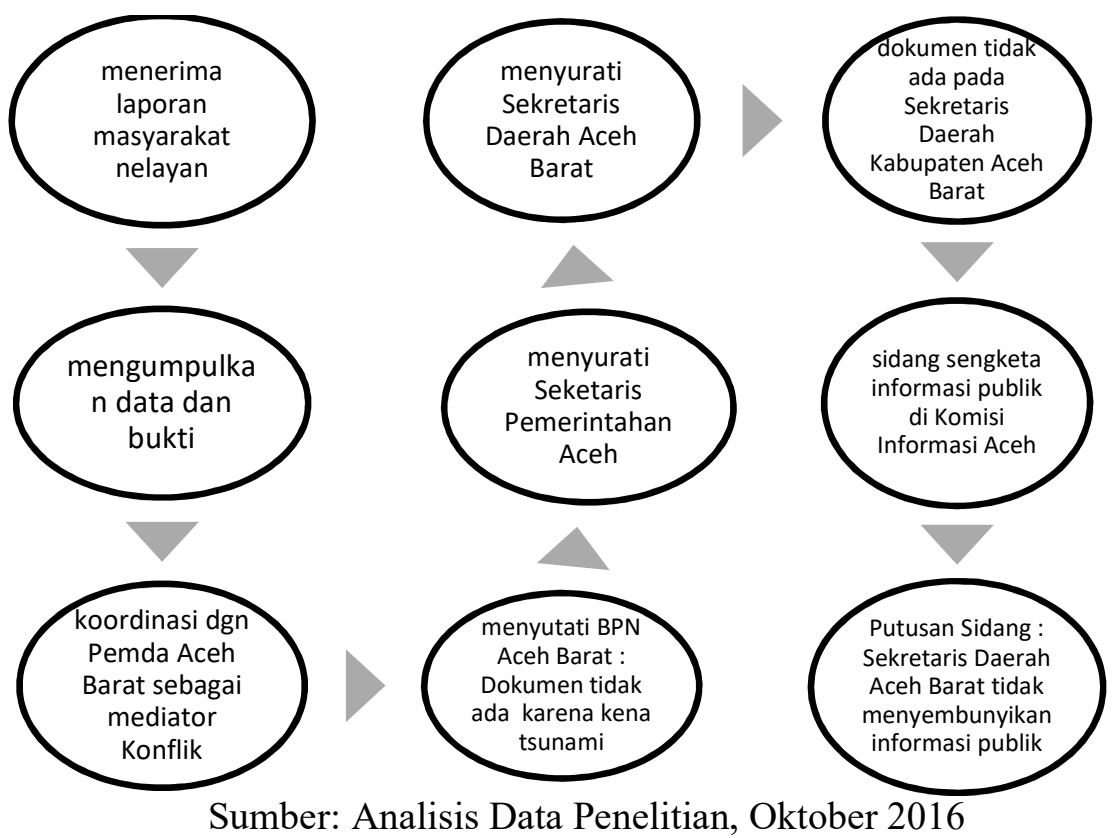

Gb. 2 Skema Upaya penyelesaian konflik yang dilakukan oleh Lembaga Bantuan Hukum Pos Meulaboh

\section{KESIMPULAN}

Berdasarkan hasil analisis data yang telah diuraikan tentang Konflik Tanah antara masyarakat nelayan dengan Pemerintah Kabupaten Aceh Barat, maka ditemukanlah beberapa kesimpulan. Kesimpulan tersebut adalah :

Berdasarkan bukti-bukti yang ada pada Pemerintah Kabupaten Aceh Barat, bahwa tanah seluas 16,1 Ha yang berada di Gampong Pasie Pinang adalah milik 
Pemerintah Kabupaten Aceh Barat berdasarkan bukti-bukti yang ada. Berdasarkan hasil penelitian maka disimpulkan bahwa, Pemerintah Kabupaten Aceh Barat tidak mengambil alih tanah seluas 16,1 Ha yang terletak di Gampong Pasie Pinang, dikarenakan secara hukum belum di hibahkan kepada masyarakat nelayan Gampong Padang Seurahet. Bahwa penyelesaian konflik yang ditempuh oleh Pemerintah Kabupaten Aceh Barat untuk menyelesaikan konflik pertanahan ini adalah dengan jalur hukum,dikarenakan penyelesaian konflik jalur persuasif (jalur non-litigasi) tidak mendapatkan kesepakatan dalam negoisasi yang dilakukan oleh Tim Pencari Fakta dan Tim Pansus DPRK Aceh Barat dengan masyarakat nelayan dan dokumen-dokumen membuktikan tanah tersebut tanah milik Pemerintah Kabupaten Aceh Barat. Masyarakat nelayan tidak mempunyai bukti apapun dikarenakan telah hilang dalam bencana tsunami 2004.

\section{Saran}

Sehubungan dengan uraian-uraian yang telah disampaikan dalam kesimpulan ini mengenai konflik tanah antara masyarakat nelayan dengan Pemerintah Kabupaten Aceh Barat, maka ditemukanlah beberapa saran untuk kebaikkan kedepan bagi lembaga pemerintahan maupun masyarakat biasa. Saran-saran tersebut seperti dibawah ini:

1. Bahwa untuk Lembaga Pemerintahan dalam membuat suatu program pemindahan masyarakat dari lokasi A kelokasi B harus segera diikuti dengan tindakan kesiapan administrasi, sehingga tidak menimbulkan masalah dikemudian hari, tidak seperti pada kasus konflik tanah antara masyarakat nelayan dengan Pemerintah Kabupaten Aceh Barat ini, dimana masyarakat telah menempati relokasi tersebut selama 6 (enam) bulan, akan tetapi tidak diiringi dengan kesiapan administrasi hibah kepada masyarakat.

2. Bahwa untuk masyarakat harus sadar hukum dan sadar administrasi akan kepentingan/keadaan yang sedang dihadapi sebagai pegangan bukti hukum yang sah dan kuat, sehingga ketika muncul suatu permasalahan maka akan ada bukti yang kuat untuk memenangkan sengekta dijalur hukum.

3. Bahwa untuk umum, penelitian ini memberikan rekomendasi penyelesian konflik secara sosiologis, akan tetapi tahap penyeleasian konflik terakhir berada dijalur hukum, karena penyelesaian konflik secara Negoisasi, Mediasi dan Konsiliasi tidak mendapatkan kesepakatan yang adil bagi kedua belah pihak yang berkonflik.'

\section{DAFTAR PUSTAKA}

Emirzon, Joni. 2001. Alternatif Penyelesaian Sengketadi Luar Pengadilan. Jakarta. PT Gramedia Pustaka Utama. 
Community: Volume 4, Nomor 2, Oktober 2018

ISSN: 2477-5746 e-ISSN: 2502-0544

Johnson, D, Paul .1990. Robert M.Z. Lawang (Pen). Teori Sosiologi Klasik Dan Modern Jilid I\&II. Jakarta.Gramedia Pustaka Utama.

Konloch,C,Graham. 2005. Perkembangan Dan Paradigma Utama Teori Sosiologi. Bandung. Pustaka Setia.

Kusnadi,H.dkk. 2001. Teori dan Manajemen Konflik (tradisonal, komtemporer dan islam). Malang. Taroda.

Kusnadi. 2000. Nelayan: Strategi Adaptasi dan Jaringan Sosial. Humaniora Utama Press. Bandung

Lacey, Hoda. 2003. How to Resolve Conflict in the Workplace : Mengelola Konflik di Tempat Kerja. Alih Bahasa Bern Hidayat, Gramedia Pustaka Utama, Jakarta.

Laporan Penyelenggaraan Pemerintahan Daerah Kabupaten Aceh Barat Tahun 2014. Pemerintahan Kabupaten Aceh Barat Tahun 2015.

Mahardika,Timur. 2000. Gerakan Masa: mengupayakan demokrasidan keadilan secara damai, Yogyakarta: Lapera Pustaka Umum.

Peraturan Pemerintah Pengganti Undang-Undang Republik Indonesia Nomor 02 Tahun 2007 Tentang "Penanganan Permasalahan Hukum Dalam Rangka Pelaksanan Rehabilitasi dan Rekontruksi Wilayah dan Kehidupan Masyarakat di Provinsi Nanggroe Aceh Darussalam dan Kepulauan Nias Provinsi Sumatera Utara"

Ralf Dahrendrof, Ali Mandan (pen), 1951. Konflik dan Konflik Dalam Masyarakat Industri: sebuah analisa kritik, jakarta, rajawali press.

Ritzer, George. 2014. Teori Sosiologi Modern. Edisi Ketujuh. Jakarta. Kencana Perdana Media Group.

Rohmah, Abu. 2002. Paradigma Resolusi Konflik Agraria. Semarang. Wali Songo Press.

Braam. P.A. Greert. 2008. Sosiologi Pemerintahan. Bogor.DF\&DC

Suhartono, Irawan. 2002. Metode Penelitian Sosial. Bandung PT. Remaja Rosdakarya.

Sumanto.1995. Metodologi Penelitian Sosial Pendidikan: Aplikasi Metode Kuantitatif dan Statistika Dalam Penelitian. Yogyakarta: Andi Offset.

Susan, Novri.2009. Pengantar Sosiologi Konflik. Jakarta. Prenada Media Group.

Surata,Agus,TuhanaTaufik Andrianto. 2001. Atasi Konflik Etnis.Yogyakarta. Global Pustaka Utama. 
187

Community: Volume 4, Nomor 2, Oktober 2018

ISSN: 2477-5746 e-ISSN: 2502-0544

Wijoyo, Suparto.1998. Penyelesaian Sengketa Lingkungan, Jakarta. Bina Aksara.

Wiwaran, I.B. 2012. Teori-teori Sosial Dalam Tiga Paradigma (Fakta Sosial, Defenisi Sosial dan Perilaku Sosial). Jakarta. Kencana Prenada Media Group. 